DOI: https://doi.org/10.15688/re.volsu.2019.1.2

UDC $330.173 .34 ; 338.262$

Submitted: 26.11 .2018

LBC 65.054

Accepted: 02.01.2019

\title{
MACROREGIONS AS THE INNOVATION IN STRATEGIZING THE SPATIAL DEVELOPMENT OF THE RUSSIAN ECONOMY ${ }^{1}$
}

\author{
Evgeniy M. Bukhvald \\ Institute of Economics, Russian Academy of Sciences, Moscow, Russian Federation \\ Olga N. Valentik \\ Institute of Economics, Russian Academy of Sciences, Moscow, Russian Federation
}

\begin{abstract}
It is extremely important for Russia as a Federal State to approve the meso-level of strategic planning within the framework of transition to the system of planing. The role of such type of planning is to link and coordinate federal strategies both of sectoral and spatial nature with the strategies of social and economic development of the regions of the Russian Federation. Until recently, such a role, although quite passively, was played by the strategies of the federal districts, which were mainly based on the principle of mechanical summation of regional strategies with an attempt to promote somehow the practice of interregional cooperation. When developing the strategic planning documents in accordance with the requirements of the $172^{\text {nd }}$ Federal law the hypothesis of linking the meso-level of such planning to macroregions, partly as an alternative to federal districts was generated. The concept of macroregion is well known in the regional development theory and it is also tested in the national economy, in particular in the form of the system of so-called "councils of national economy" (Sovnarkhoz). However, in modern conditions taking into account the realities of Russia and the specifics of the economy of the market type, the approval of the macroregion as a special subject of strategic planning requires a wide range of legal, economic and institutional prerequisites which are studied in this article.
\end{abstract}

Key words: strategic planning, spatial regulation, Federal districts, macroregions, powers, legislative regulation.

Citation. Bukhvald E. M., Valentik O. N. Macroregions as the Innovation in Strategizing the Spatial Development of the Russian Economy. Regionalnaya ekonomika. Yug Rossii [Regional Economy. The South of Russia], 2019, vol. 7, no. 1, pp. 18-28. (in Russian). DOI: https://doi.org/10.15688/re.volsu.2019.1.2

УДК $330.173 .34 ; 338.262$

Дата поступления статьи: 26.11.2018

ББК 65.054

Дата принятия статьи: 02.01.2019

\section{МАКРОРЕГИОНЫ КАК НОВАЦИЯ СТРАТЕГИРОВАНИЯ ПРОСТРАНСТВЕННОГО РАЗВИТИЯ ЭКОНОМИКИ РОССИИ ${ }^{1}$}

\author{
Евгений Моисеевич Бухвальд \\ Институт экономики Российской академии наук, г. Москва, Российская Федерация \\ Ольга Николаевна Валентик \\ Институт экономики Российской академии наук, г. Москва, Российская Федерация
}

\begin{abstract}
Аннотация. Для России как государства федеративного типа в рамках перехода к системе стратегического планирования чрезвычайно важно утвердить мезоуровень такого планирования. Его роль состоит в увязке и согласовании федеральных стратегий как отраслевого и пространственного характера со стратегиями социально-экономического развития субъектов Российской Федерации. До последнего времени, хотя и достаточно пассивно, такую роль выполняли стратегии федеральных округов, которые преимущественно основывались на принципе механи-
\end{abstract}

(с) Бухвальд Е.М., Валентик О.Н., 2019 
ческого суммирования региональных стратегий, но с попыткой неким образом продвинуть идеи межрегионального сотрудничества. При разработке документов стратегического планирования сообразно требованиям 172-го федерального закона возникла гипотеза привязки мезоуровня такого планирования к макрорегионам, в том числе в виде возможной альтернативы федеральным округам. Само по себе понятие «макрорегион» хорошо известно в теории регионалистики, а также апробировано в отечественной практике, в частности, в виде системы так называемых советов народного хозяйства (совнархозов). Однако в современных условиях, с учетом реалий России как государства федеративного типа и специфики экономики рыночного типа утверждение макрорегиона как особого субъекта стратегического планирования требует широкого круга правовых, экономических и институциональных предпосылок, которые и рассматриваются в данной статье.

Ключевые слова: стратегическое планирование, пространственное регулирование, федеральные округа, макрорегионы, полномочия, законодательное регулирование.

Цитирование. Бухвальд Е. М., Валентик О. Н. Макрорегионы как новация стратегирования пространственного развития экономики России // Региональная экономика. Юг России. 2019. Т. 7, № 1. С. 18-28. DOI: https://doi.org/ 10.15688/re.volsu.2019.1.2

\section{Постановка проблемы}

Прошедший в октябре 2018 г. в Санкт-Петербурге XVII Форум по стратегическому планированию как всегда отдельное внимание обратил на проблемы пространственного стратегирования и в целом - на формирование эффективно действующей вертикали стратегического планирования в стране. Последнее чрезвычайно важно в условиях государства федеративного типа, так как только согласование и взаимодействие в рамках единой вертикали всех уровней публичной власти обеспечивает эффективность постановки и достижения национальных приоритетов стратегического характера. Одним из важных аспектов решения этой задачи выступает вопрос о мезоуровне государственного управления и стратегирования, расположенном между Федерацией и ее субъектами. Это - управленческий уровень, опосредующий федеральный и субфедеральный уровни стратегического планирования и во многом согласующий его отраслевые и пространственные слагаемые. Обсуждения, проведенные на форуме, показали, что пока четкого представления о том, как будет функционировать этот мезоуровень стратегического планирования в стране, как он будет согласовываться с новыми идеями экономического районирования в Российской Федерации, пока не сформировалось.

\section{Отраслевое и пространственное планирование: единство в противоположности}

Следует отметить, что экономическому районированию как необходимой предпосылке пространственного планирования придавалось важное значение в таком формальном, по сути, федеративном государстве, как СССР. Так, первое практическое воплощение идея экономического районирования страны нашла в плане ГОЭЛРО (1920 г.). В последнем сообразно его исходной целевой функции (распределение энергогенерирующих мощностей, а также развитие транспортной инфраструктуры на территории страны) были выделены 8 крупных районов. В 1921 г. Госплан России, развивая основные идеи плана ГОЭЛРО, предложил схему выделения на территории страны 21 экономического района. При этом структуризация районов определялась значительным числом факторов, в числе которых выделялись пригодно-географические особенности территорий, традиционные для них виды хозяйственной деятельности, уровень профессиональной подготовки трудоспособного населения, наличие объектов производственной и социальной инфраструктуры и прочее.

В последующий период система крупных экономических районов (макрорегионов) в СССР неоднократно пересматривалась; изменялось их количество, причины отграничения и уточнялся их состав. Первый пятилетний план (1929-1932 гг.) был сформирован по 4 типам макрорегионов (индустриальные районы, сельскохозяйственные районы, смешанный тип районов и лесные районы) и 24 крупным районам; второй (1933-1937 гг.) - по 32 районам и зоне Севера; третий (1938-1942 гг.) по 9 крупным районам и 10 союзным республикам. В начале 1960-х гг. в СССР была сформирована новая система территориального районирования, которая основывалась на выделении 18 крупных экономических районов, в том числе 10 - в составе тогдашней РСФСР.

При переходе к системе рыночного хозяйствования с существенным изменением функций 
и механизмов государственного управления хозяйственными и социальными процессами, роль районирования как инструмента политики регулирования пространственной структуры национальной экономики, конечно, модифицировалась. Она, прежде всего, должна была адаптироваться к реалиям новой федеративной государственности (регионы и макрорегионы как система субъектов Федерации) и также к условиям, когда государство располагает лишь ограниченным кругом инструментов прямого и косвенного воздействия на территориальную картину размещения производительных сил в стране. Эти условия тем более подчеркивали необходимость эффективно действующего мезоуровня государственного управления.

В Конституции РФ 1993 г. такой уровень государственной власти не предусмотрен: основная конституционная идея Российской Федерации построена на прямом взаимодействии между Федерацией и ее субъектами, причем на принципе равноправия всех субъектов Федерации в этой системе взаимодействий. Сказанное не означает, что любая попытка сформировать некое промежуточное управленческое звено во взаимоотношениях Федерации и ее субъектов заведомо неконституционна. Все дело в наличии качественной правовой базы и ее соответствии принципам российской федеративной государственности. Одним из таких принципов, иллюстрирующим возможности и преимущества государства федеративного типа, выступает наличие у субъектов Федерации возможностей проведения собственной экономической политики, включая и движение по пути активной межрегиональной экономической интеграции. При этом, помимо согласования интересов Федерации и ее субъектов, а также их программно-плановых документов, именно содействие такой интеграции выступает одной из ведущих функций мезоуровня управления.

Можно выделить ряд факторов, предполагающих важность процессов межрегиональной экономической интеграции, а также функционирования особого мезоуровня управления социально-экономическими процессами в стране. Прежде всего, они касаются необходимости соблюсти свойственный всякому федеративному государству баланс элементов централизации и децентрализации в управлении. Кроме того, развитие кооперационных взаимодействий между субъектами Федерации, в том числе и на пространстве макрорегионов, позволяет участникам хозяйственной деятельности существенно экономить на затратах инвестиционного и логистического характера, прежде всего, за счет совместного формирования крупных территориально-производственных комплексов, многоотраслевых кластеров и прочего.

В самом начале 1990-х гг. «обвал» экономики планового типа и присущих ей механизмов межрегиональных интеграционных процессов генерировал в регионах тенденции «автаркии», нагромождения межрегиональных экономических границ и прочего. Естественно, что для любой экономики такой путь «развития» носит заведомо тупиковый характер. В связи с этим по мере становления начал рыночного хозяйствования и управления субъекты Федерации во многом приняли на себя решение задачи расширения межрегиональных хозяйственных связей. Эта задача решалась, в частности, путем заключения двух- и многосторонних договоров о сотрудничестве, которые так или иначе стимулировали межрегиональные взаимодействия, то есть связывали друг с другом хозяйствующие субъекты этих регионов. Какая-либо планово-координирующая роль особого мезоуровня управления в данной ситуации явно не просматривалась, а сами названные выше договоры устойчивого позитивного эффекта не давали.

Неслучайно после начала экономических и социально-политических реформ в России «ниша» такого промежуточного звена управления пустовала недолго. Еще до принятия Конституции РФ 1993 г. «Квази-мезоуровнем» российской экономики стали так называемые межрегиональные ассоциации экономического взаимодействия. Их деятельность получила правовую базу в виде Федерального закона «Об общих принципах организации и деятельности ассоциаций экономического взаимодействия субъектов Российской Федерации» [Федеральный закон от 17.11.1999 № 221-Ф3]. Всего в период 1990-х гг. было сформировано восемь ассоциаций экономического взаимодей ствия: «Северо-Запад», «Центральная Россия», «Черноземье», «Ассоциация республик, краев и областей Северного Кавказа», «Большая Волга», «Уральская ассоциация», «Сибирское соглашение», «Дальневосточная ассоциация».

Закон не закреплял за ассоциациями какиелибо управленческие функции, свойственные органам публичной власти. Но их значимость для регионов - участников соглашений - подчеркивалась, прежде всего, уже названной выше спецификой условий начала 1990-х гг., когда рыноч- 
ные механизмы экономических взаимодействий субъектов хозяйствования различных регионов еще только формировались и нуждались в определенных мерах поддержки со стороны властных структур.

Однако «золотой век» этих ассоциаций продолжался недолго. Уже в 2000 г. их практическая значимость была потеснена в результате учреждения федеральных округов, созданных на основе Указа Президента РФ [Указ Президента РФ от 13.05.2000 № 849]. Первоначально были созданы 7 округов. Затем их стало 8 за счет разделения Южного и Северо-Кавказского округов (2010 г.), а в 2014 г. - 9 за счет создания Крымского федерального округа. В настоящее время действуют 8 федеральных округов. Эксперты уже неоднократно отмечали, что правовой статус федеральных округов и действующего в них аппарата полномочного представителя Президента РФ выглядит достаточно неопределенно [Бухвальд, 2016; Ширяева, 2017]. Формально этот аппарат выступает частью Администрации Президента РФ. Функции полномочного представителя согласно утвержденному Указом положению носят в основном контрольный и церемониальный характер.

С точки зрения задач экономического свойства за полномочными представителями Президента РФ в федеральных округах закреплялась функция разработки, причем именно совместно с межрегиональными ассоциациями экономического взаимодействия субъектов Российской Федерации, программ их социально-экономического развития. Однако в последние годы роль федеральных округов сместилась с текущих и среднесрочных программ на формирование и согласование стратегических документов, отражающих долговременные горизонты развития российских регионов. В результате, в той практике социально-экономического стратегирования, которая сложилась в стране за последние 10-15 лет, важное место заняли стратегии развития федеральных округов, которые начали формироваться с 2006 года [Смирнова, 2016]. В настоящее время утвержденные стратегии имеют все федеральные округа России.

Такие стратегии нуждаются в весьма взвешенной оценке. С одной стороны, их «директивная» сила для стратегий субъектов Федерации, входящих в данный федеральный округ, четко не обозначена. С другой стороны, нет оснований говорить, что стратегии федеральных округов не более чем кумулятивный итог соответствую- щих региональных документов. Скорее всего, стратегии федеральных округов наиболее значимы даже не для самих регионов того или иного округа, а для федерального центра, они обозначают его ключевые задачи по социально-экономическому развитию данного макрорегиона, в том числе через федеральную поддержку наиболее значимых межрегиональных программ и проектов, в частности, по развитию магистральной транспортной и иной инфраструктуры на данной территории. Принятие таких стратегий во многом позволяло сформировать основные методические, процедурные и документальные основы социально-экономического стратегирования на мезоуровне, тем не менее постоянно требовало уточнить правовой статус этих документов, включая соподчиненность и логическую последовательность стратегий разного уровня и соответствующий круг полномочий федеральных округов как субъектов или агрегаторов практики пространственного стратегирования. По сути, эти задачи так и не были решены.

Анализ имеющихся стратегических документов федеральных округов показывает, что они, во-первых, методологически и даже содержательно весьма разнородны и, во-вторых, объективно характеризуются слабой проработкой тех управленческих процедур, которые должны обеспечить реализацию указанных стратегий. Такая ситуация неслучайна. Федеральные округа в действующем виде не имеют «собственных» инструментов социально-экономического регулирования и «собственных» бюджетных средств. Интегрируя стратегии нескольких субъектов Федерации, они неизбежно вынуждены считаться с тем, что в каждом регионе есть своя специфика институтов и инструментов социально-экономического регулирования, налогово-бюджетной политики и прочего. В таких условиях крайне сложно обозначить единую для стратегии федерального округа институционально-управленческую основу. Однако предложения законодательно отрегулировать статус федеральных округов и их полномочия, в частности, в контексте стратегирования социальноэкономического развития соответствующих территорий и входящих в нее субъектов Федерации, так и не были реализованы. Распределение субъектов Федерации по федеральным округам продолжает сохранять определенные черты произвольности, о чем свидетельствует предпринятая в ноябре 2018 г. передача Республики Бурятия и Забайкальского края в Дальневосточный федеральный округ. 
Наконец, следует отметить, что в последние два десятилетия функцию «мезоуровня» государственного управления приняли на себя территориально-привязанные федеральные органы исполнительной власти. Мы имеем в виду не федеральный орган власти, ответственный за государственную политику регионального развития. После многочисленных модификаций такой федеральный орган власти (Министерство регионального развития РФ) был упразднен, и, судя по всему, окончательно в 2014 году. Частично этот орган был замещен рядом локальнорегиональных министерств. Речь идет о федеральных органах государственной власти, созданных не для осуществления управленческой деятельности в том или ином «векторе» хозяйственного или социального развития страны, а для комплексного решения проблем определенной части территории страны [Колесниченко, 2016].

Такие «территориальные» ведомства, полагаем, создают определенное неравенство в позиционировании субъектов Федерации во властно-управленческой вертикали: одни регионы должны взаимодействовать с федеральными органами исполнительной власти напрямую, другие в этом случае имеют некого посредника или лоббиста в виде соответствующих «территориальных» министерств. Такие ведомства лишь дублируют соответствующие государственные программы территориального развития. При этом круг субъектов Федерации, находящихся «под эгидой» того или иного локально-территориального министерства, специально никак не мотивировался и не находится вне прямой связи с соответствующими федеральными округами, хотя, как было отмечено выше, расширение ареала действия Минвостокразвития РФ привело к передаче двух дополнительных субъектов Федерации в состав Дальневосточного федерального округа.

Нынешние территориальные министерства по своим задачам отчасти напоминают легендарные совнархозы советской эпохи [Подольский, Давыдов, 2016; Щербакова, 2013]. Выделяются два основных этапа, когда такие институты получали преобладающую роль в управлении экономикой страны.

Впервые совнархозы появились в России после октября 1917 года. Они находились в подчинении у ВСНХ (Всероссийского совета народного хозяйства). Совнархозы обеспечивали реализацию политики ВСНХ на местах и были созданы в губерниях, областях и даже районах.
На данном этапе ключевой задачей совнархозов было восстановление производительных сил страны, распределение ресурсов для нужд каждого района и вместе с тем контроль за выполнением директив центра на местах. Однако уже в середине 1920-х гг. деятельность совнархозов как институтов восстановительного периода оказалась бессмысленной ввиду курса на жесткую децентрализацию руководства экономикой страны через органы отраслевого управления.

Вторая «волна» создания совнархозов пришлась на середину 1950-х гг. в рамках поиска путей совершенствования управления, прежде всего, в сфере промышленности и строительства. В процессе перехода к преимущественной роли территориального принципа в планировании и управлении вся территория СССР была разделена на экономические районы, во главе которых стояли совнархозы. Были упразднены 10 отраслевых министерств. Формально цель создания совнархозов как территориальных органов управления состояла в попытке приближения руководства к низовым звеньям экономики - предприятиям и объединениям. Кроме того, предполагалось, что совнархозы обеспечат комплексный подход к социально-экономическому развитию территорий. На протяжении второй половины 1957 г. в СССР были созданы сто пять совнархозов, хотя в последующем они претерпели существенную централизацию.

Указанные реформы вызвали, мягко говоря, двойственную реакцию и даже откровенное отторжение со стороны партийно-бюрократической номенклатуры, так как явно ограничивали управленческую власть ее верхушки. Да и в целом территориальный принцип предполагает значительно большую степень децентрализации управления экономикой, что не соответствовало принципам жесткой вертикали партийно-государственной машины советского типа. По оценкам экономистов, введение совнархозов дало определенный позитивный эффект для народного хозяйства, который, однако, был обесценен рядом иных крупных ошибок в руководстве экономикой, а именно отсутствием действенных стимулирующих механизмов для хозяйствующих субъектов - предприятий; неоправданным форсированием процессов централизации в сельском хозяйстве с ликвидацией тысяч сельских поселений и прочим. Даже в условиях откровенного правового субъективизма, характерного для экономики советского типа, управленческая деятельность совнархозов постоянно сталкивалась с неурегулированностью ее 
правовых основ. Ключевой ошибкой этого этапа реформ явилось также разделение областных комитетов КПСС на промышленные и сельскохозяйственные, следствием чего стал управленческий хаос на местах. После отставки Н.С. Хрущева в октябре 1964 г. новое руководство КПСС свернуло проведенные им реформы управления. Территориальные органы управления - совнархозы - были упразднены, и в стране вновь появились отраслевые министерства.

\section{Макрорегионы: потенции стратегического планирования}

По сути, сегодня, основываясь на дискуссиях вокруг ключевых проблем становления стратегического планирования, можно говорить о новом этапе поиска баланса между отраслевым и территориальным принципами государственного управления социально-экономическими процессами. Конечно, два таких весомых фактора, как переход к модели рыночной экономики и к реальному федеративному устройству российской государственности, накладывают весомый отпечаток на представления об оптимальном балансе отраслевого и пространственного подходов в управлении, причем явный сдвиг, казалось бы, должен происходить в пользу последнего. Тем не менее в течение четверти века после начала российских реформ так же, как и в условиях плановой экономики и высокоцентрализованного государства, в России отраслевой подход в управлении, в том числе и в контексте развития его стратегических начал, отчетливо преобладал над пространственным. В результате вопрос о деформациях отраслевой структуры российской экономики дебатировался практически постоянно (хотя и столь же малорезультативно), а вот вопрос о деформациях пространственной структуры экономики, а также о необходимой мере децентрализации управления всплывал лишь периодически и, как складывается впечатление, наиболее остро обозначился лишь в самое последнее время.

Как показали обсуждения на форуме, на данный момент остаются открытыми многие вопросы, принципиально важные для формирования методологических основ и методических подходов к стратегированию пространственного развития российской экономики, в том числе и на ее мезоуровне. Имеющаяся нормативно-правовая база, содержащая и ключевой в данном смысле 172-й Ф3 [Федеральный закон от 28.06.2014 № 172-Ф3], по общему мнению, не дает исчерпывающего ответа на возникающие здесь вопросы.
Прежде всего, что же такое обозначенная законом стратегия макрорегиона как «стратегия для двух и более субъектов Российской Федерации»? Механическая сумма двух региональных стратегических документов или некое отдельное, самостоятельное целеполагание для развития данной территории как целого? Есть ли максимальный предел численного состава макрорегиона с точки зрения оптимальности пространства социально-экономического стратегирования? Можно ли более конкретно определить ту систему признаков, наличие которых формирует основания для группировки тех или иных субъектов Федерации в составе единого макрорегиона как объекта и как субъекта мезоуровня стратегического планирования? В настоящее время проект Стратегии пространственного развития выделяет несколько принципов формирования макрорегионов, из которых только один (географический) имеет конкретный смысл (территориальная общность субъектов Российской Федерации, характеризующаяся их соседским положением).

Все остальные «принципы», предлагаемые проектом Стратегии (значительный потенциал межрегионального взаимодействия и кооперации; наличие в составе каждого макрорегиона одного или нескольких крупных центров экономического роста; наличие или возможность создания объектов транспортной, энергетической, информационно-коммуникационной инфраструктуры, а также объектов отраслей социальной сферы федерального значения, способствующих повышению доступности услуг указанных отраслей в пределах макрорегиона и прочее), носят настолько общий характер, что позволяют оправдать практически любой состав каждого из макрорегионов.

Наконец, даже чисто практически важен такой вопрос: заменят ли стратегии макрорегионов стратегии федеральных округов или будут действовать параллельно им? Возможно ли вообще эффективное социально-экономическое стратегирование на мезоуровне вне наличия особого субъекта такой плановой деятельности, то есть только, как формулирует закон, силами уполномоченного федерального ведомства?

Какое место могут и должны занять макрорегионы в системе стратегического планирования, в частности, в управлении пространственными характеристиками российской экономики? Зачем вообще вновь акцентируется вопрос о макрорегионах? Эти вопросы многократно возникали в ходе обсуждений на прошедшем фору- 
ме по стратегическому планированию. В проекте Стратегии пространственного развития, где эта институция обозначена наиболее конкретно, ее роль мотивируется необходимостью повышения конкурентоспособности экономик субъектов Федерации за счет развития перспективных экономических специализаций и межрегионального сотрудничества.

Подобная мотивация «до боли» напоминает то, что более чем полвека назад говорилось в пользу совнархозов. Но в условиях плановой экономики совнархозы, как «экономические администраторы» территорий, действительно имели практическую возможность активизировать межрегиональное сотрудничество, активно воздействовать на экономическую специализацию регионов и прочее. Но сейчас ситуация иная. Макрорегионы не имеют исполнительной власти; у них нет собственных рычагов управления и почему, собственно, чисто географическая нарезка макрорегионов должна стимулировать такое сотрудничество, не ясно. Да и излишний акцент на проблему межрегиональной кооперации в условиях современной глобализирующейся экономики уже не выглядит столь убедительно.

Аргументация проекта Стратегии пространственного развития относительно того, что такую роль могут выполнить стратегии и программы развития макрорегионов, также не убеждает. Если эти инструменты не сработали на «поле» федеральных округов, почему они должны сработать на близком по сути «поле» макрорегионов? Имеющийся на сей счет официальный документ [Постановление Правительства РФ от 08.08.2015 № 822] носит чисто технический характер и не содержит ни указаний на критерии выделения макрорегионов, ни аргументов в пользу отличий и преимуществ стратегий макрорегионов перед имеющимися стратегиями федеральных округов.

С точки зрения той логики стратегического планирования, которая обозначена в 172-м Ф3, макрорегионы можно рассматривать и как объект, и как субъект управления. Роль макрорегионов как субъекта управления безусловна с позиции активного соучастия в реализации крупных транспортных проектов, формирующих основу целостности страны как экономического пространства. Это также касается попыток целого ряда субъектов Федерации совместно реализовать крупные системные межрегиональные инвестиционные проекты типа «Белкомур», «Урал промышленный - Урал полярный» и прочее.
Однако наибольшие сложности связаны с определением того, как макрорегионы смогут реализовать роль субъекта стратегического планирования в отношении регионов, попадающих в состав данного макрорегиона. Теоретически, как показали дискуссии на форуме, можно предположить использование одной из трех моделей осуществления стратегического планирования на мезоуровне: а) на основе действующих федеральных округов; б) на основе нормативно выделенных макрорегионов, совпадающих или несовпадающих с федеральными округами; в) при параллельном использовании двух субъектов стратегического планирования на мезоуровне - и федеральных округов, и макрорегионов.

Чтобы определиться с этими моделями, необходимо, как подчеркивали участники форума, прежде всего, уточнить, что такое макрорегион в системе отношений стратегического планирования: чисто географическое пространство, условно собранное под некие схожие характеристики, или некая формальная, юридически закрепленная институция, имеющая возможности как-то практически воздействовать на социально-экономическое развитие того пространства, которое она интегрирует? Предполагается, что в состав макрорегионов будут включены крупные центры экономического роста, связанные между собой элементами магистральной инфраструктуры, обеспечивающими, в том числе, возможность продвижения продукции на внешние рынки. Однако эти объективные экономические посылки формирования макрорегионов в целях стратегического планирования, в том числе и на мезоуровне, требуют достаточно четких институционально-правовых рамок [Селимханов, 2018].

Однако, как было отмечено выше, действующее законодательство о стратегическом планировании (172-й Ф3, ст. 3) не дает исчерпывающего определения понятия «макрорегион» и критериев их формирования. Все сводится к констатации того, что макрорегион - часть территории страны, включающая в себя территории двух и более субъектов Российской Федерации, социально-экономические условия в пределах которой требуют выделения отдельных направлений, приоритетов, целей и задач социально-экономического развития при разработке документов стратегического планирования. Видимо, для целей стратегирования пространственного развития это определение нуждается в дополнительных уточнениях. 
Во-первых, данное определение вовсе не исходит из того, что субъекты Федерации, включаемые в тот или иной макрорегион, обязательно должны быть соседствующими, хотя в проекте Стратегии пространственного развития реализуется именно этот критерий. Во-вторых, очевидно предполагается, что субъекты Федерации, входящие в тот или иной макрорегион, должны характеризоваться примерно равным уровнем развития и схожестью стоящих перед ними проблем, так как только в этом случае возможна и целесообразна разработка единого для макрорегиона документа стратегического планирования. Однако в проекте Стратегии пространственного развития макрорегионы, сформированные по принципу «соседства», на деле характеризуются существенными разрывами в социально-экономическом развитии причисленных к ним субъектов Федерации [Михеева, 2018].

Кроме того, с точки зрения позиционирования мезоуровня стратегического планирования в 172-м Ф3, на наш взгляд, имеется определенное противоречие. Данный законодательный акт (ст. 11) рассматривает стратегии социально-экономического развития макрорегионов как документы федерального уровня. Этот вопрос также представлен в ст. 21 данного закона, однако достаточно формально и неконкретно. Но в целом очевидно, что закон с точки зрения позиционирования в системе стратегического планирования отдает приоритет роли макрорегионов как объекта, а не как субъекта такого планирования. Никакого конкретного субъекта мезоуровня стратегического планирования закон не определяет. Все отдается «на откуп» до сих пор никак конкретно не обозначенному федеральному органу исполнительной власти. Такая ситуация не только непродуктивна, но даже и противоречит уже фактически сложившейся практике формирования стратегий федеральных округов, которые никогда не «спускались» им сверху [Седов, 2015].

Наконец, в связи с рассматриваемой проблемой необходимо обратиться еще к двум документам, целевая функция которых определялась необходимостью сформулировать основные требования к Стратегии пространственного Развития Российской Федерации ${ }^{1}$. Это - Постановление Правительства РФ «О содержании, составе, порядке разработки и утверждения стратегии пространственного развития Российской Федерации, а также о порядке осуществления мониторинга и контроля ее реализации» [Постановление Правительства РФ от 20.08.2015 № 870], а также Указ Президента РФ «Об утверждении Основ государственной политики регионального развития Российской Федерации на период до 2025 года» [Постановление Правительства РФ от 08.08.2015 № 822].

Постановление Правительства РФ 2015 г. указывает на то, что Стратегия пространственного развития должна закрепить «состав макрорегионов на территории Российской Федерации». Вопрос о федеральных округах и их роли в стратегировании пространственного развития в документе вообще не поднимается. Указ Президента РФ 2017 г. исходит из необходимости утверждения на период до 2025 г. программ социальноэкономического развития макрорегионов либо в действующих границах федеральных округов, либо на основе изменения этих границ. Из этого указания можно сделать вывод, что в практике пространственного социально-экономического стратегирования макрорегионы либо совпадают с действующими границами федеральных округов или федеральные округа корректируются под вновь образованную систему макрорегионов. В последнем случае как бы упраздняется дуализм 172-го Ф3 в понимании мезоуровня стратегического планирования и макрорегионы реализуют функцию объектов и субъектов такого планирования именно через стратегии федеральных округов. Такой вариант представляется более целесообразным, однако он неизбежно приводит к мысли о том, зачем тогда вообще нужно вводить в систему пространственного регулирования такой институт, как макрорегионы?

При каких условиях действующие федеральные округа могут закрепить за собой статус конструктивных, а не сугубо формальных субъектов стратегического планирования, в частности, на мезоуровне? Как мы полагаем, кардинально решить эту задачу может только принятие давно востребованного практикой управления Федерального закона «О федеральных округах в Российской Федерации». Закон должен сформировать правовую базу функционирования федеральных округов как субъекта стратегического планирования, например, на основе механизма «делегированных полномочий».

Иная, вполне конструктивная возможность решить названную задачу - создание Федерального агентства по стратегическому планированию, подчиненного непосредственно Президенту РФ. Создание такого федерального органа исполнительной власти, а также его территориальных структур на уровне федеральных окру- 
гов может четко позиционировать роль округов как субъекта стратегического планирования на мезоуровне и в целом - существенно повысить эффективность функционирования пространственного «среза» этого планирования. В Положении о таком федеральном агентстве могли бы быть зафиксированы сведения о том, что это агентство располагает территориальными структурами (подразделениями), функционирующими в соответствующих федеральных округах и под непосредственным контролем представителей Президента РФ в соответствующих округах.

Округа не могут быть частью бюджетной системы страны и иметь собственный «полноценный» бюджет, здесь отсутствует представительный орган власти. Однако необходимый для деятельности округа как субъекта стратегического планирования фонд финансовых ресурсов мог бы быть создан за счет сложения средств федерального и региональных бюджетов с целью его использования для финансирования наиболеезначимых межрегиональных инвестиционных проектов.

\section{Заключение}

В условиях Российской Федерации как государства федеративного типа эффективное функционирование всей вертикали стратегического планирования, включая и решение задач пространственного стратегирования, возможно только при наличии особого мезоуровня планирования, имеющего адекватное правовое, институциональное и экономическое обеспечение. В настоящее время утверждение в этой роли макрорегионов практически возможно и целесообразно только через такой субъект управления, как федеральные округа. Законодательной базой их деятельности должен быть Федеральный закон «О федеральных округах в Российской Федерации» и корреспондирующие ему поправки и дополнения в Федеральный закон «О стратегическом планировании в Российской Федерации». Эти законодательные новации должны четко определять место и роль федеральных округов как объектов и субъектов стратегического планирования, включая логическую последовательность и соподчиненность стратегий макрорегионов и стратегий входящих в него субъектов Российской Федерации.

\section{ПРИМЕЧАНИЕ}

${ }^{1}$ Ожидавшаяся участниками Форума возможность обсудить итоговый вариант данной стратегии так и не реализовалась, хотя ранее было анонсировано принятие этого документа Правительством РФ в октябре 2018 года. Дальнейшая отсрочка с принятием этого документа может быть объяснена негативными результатами его обсуждения на слушаниях в Общественной палате РФ (август 2018 г.) и в Совете Федерации Федерального собрания РФ (октябрь 2018 г.).

\section{СПИСОК ЛИТЕРАТУРЫ}

Бухвальд Е. М., 2016. Какой должна быть роль федеральных округов в системе стратегического планирования в России? // Федерализм. № 3. C. 27-40.

Колесниченко Ю. Ю., 2016. Федеральное министерство как орган территориального управления (на примере Северо-Кавказского федерального округа) // Апробация. № 2 (41). С. 145-147.

Михеева Н. Н., 2019. Стратегия пространственного развития: новый этап или повторение старых ошибок? // ЭКО. № 5 (527). С. 158-178.

Подольский С. И., Давыдов А. Ю., 2016. «Система совнархозов является безусловно прогрессивной»: из истории Ленинградского совета народного хозяйства (1957-1966 годы) // Новый исторический вестник. № 4 (50). С. 80-89.

Постановление Правительства РФ от 08.08.2015 № 822 «Об утверждении Положения о содержании, составе, порядке разработки и корректировки стратегий социально-экономического развития макрорегионов». Доступ из информационно-правового портала «Гарант».

Постановление Правительства РФ от 20.08.2015 № 870 «О содержании, составе, порядке разработки и утверждения стратегии пространственного развития Российской Федерации, а также о порядке осуществления мониторинга и контроля ее реализации». Доступ из информационно-правового портала «Гарант».

Седов Е.В., 2015. Макрорегионы и федеральные округа как территориальные единицы стратегического планирования // Системное управление. № 4 (29). C. 31 .

Селимханов 3., 2018. Экономические и организационные предпосылки формирования макрорегиона // Экономика и управление: проблемы, решения. T. 1. № 6. С. 41-46.

Смирнова О. О., 2016. Новый взгляд на функции полномочных представителей Президента Российской Федерации в федеральных округах в свете требований к стратегиям макрорегионов // Отечественная юриспруденция. № 2. С. 4-9.

Указ Президента РФ от 16.01.2017 № 13 «Об утверждении Основ государственной политики регионального развития Российской Федерации на период до 2025 года». Доступ из справ.-правовой системы «КонсультантПлюс». 
Указ Президента РФ от 13.05.2000 № 849 «О полномочном представителе Президента Российской Федерации в федеральном округе». Доступ из справ.-правовой системы «КонсультантПлюс».

Федеральный закон от 28.06.2014 №172-Ф3 «О стратегическом планировании в Российской Федерации». Доступ из информационно-правового портала «Гарант».

Федеральный закон от 17.11.1999 № 211-Ф3 «Об общих принципах организации и деятельности ассоциаций экономического взаимодействия субъектов Российской Федерации». Доступ из информационно-правового портала «Гарант».

Ширяева А. И., 2017. История становления и развития института полномочных представителей Президента РФ в федеральных округах // Конституционализм и государствоведение. № 2 (10). С. 132-137.

Щербакова Т. И., 2013. Совнархозы: правовое положение, экономический потенциал, результаты деятельности // Экономическая история. № 2 (21). C. 86-95.

\section{REFERENCES}

Bukhvald E.M., 2016. Kakoy dolzhna byt rol federalnykh okrugov v sisteme strategicheskogo planirovaniya $\mathrm{v}$ Rossii? [What Should Be the Role of Federal Districts in the System of Strategic Planning in Russia?]. Federalizm [Federalism], no. 3, pp. 27-40.

Kolesnichenko Yu.Yu., 2016. Federalnoe ministerstvo kak organ territorialnogo upravleniya (na primere Severo-Kavkazskogo federalnogo okruga) [The Federal Ministry as the Body of Territorial Administration (on the Example of the North Caucasus Federal District)]. Aprobatsiya [Approbation], no. 2 (41), pp. 145-147.

Mikheeva N.N., 2018. Strategiya prostranstvennogo razvitiya: novyy etap ili povtorenie starykh oshibok? [Spatial Development Strategy: a New Stage or a Repetition ofOld Mistakes?]. EKO [ECO], no. 5 (527), pp. 158-178.

Podolskiy S.I., Davydov A.Yu., 2016. Sistema sovnarkhozov yavlyaetsya bezuslovno progressivnoy: iz istorii Leningradskogo soveta narodnogo hozyaystva (1957-1966 gody) [The Economic Councils Are Certainly Progressive: From the History of the Leningrad Council of National Economy(1957-1966)]. Novyy istoricheskiy vestnik [New Historical Journal], no. 4 (50), pp. 80-89.

Postanovlenie Pravitelstva RF ot 08.08.2015 № 822 «Ob utverzhdenii Polozheniya o soderzhanii, sostave, poryadke razrabotki i korrektirovki strategiy sotsialno-ekonomicheskogo razvitiya makroregionov» [Decree of the Government of the Russian Federation of August 8, 2015 No. 822 "On the Approval of the Provision on Content, Composition and Procedure for the Development and Adjustment of Strategies for Socio-Economic
Development of Macroregions"]. Access from Information Legal Portal "GARANT".

Postanovlenie Pravitelstva RF ot 20.08.2015 № 870 «O soderzhanii, sostave, poryadke razrabotki $i$ utverzhdeniya strategii prostranstvennogo razvitiya Rossiyskoy Federatsii, a takzhe o poryadke osushchestvleniya monitoringa i kontrolya ee realizatsii») [Decree of the Government of the Russian Federation of August 20, 2015 No. 870 "On the Content, Composition, Development and Approval of the Strategy of Spatial Development of the Russian Federation, as Well as on the Procedure for Monitoring and Control of Its Implementation"]. Access from Information Legal Portal "GARANT".

Sedov E.V., 2015. Makroregiony i federalnye okruga kak territorialnye edinitsy strategicheskogo planirovaniya [Macroregions and Federal Districts as Territorial Units of Strategic Planning]. Sistemnoe upravlenie [System Management], no. 4 (29), p. 31.

Selimkhanov Z., 2018. Ekonomicheskie i organizatsionnye predposylki formirovaniya makroregiona [Economic and Organizational Prerequisites for the Formation of the Macroregion]. Ekonomika i upravlenie: problemy, resheniya [Economics and Management: Problems, Solutions], vol. 1, no. 6, pp. 41-46.

Smirnova O.O., 2016. Novyy vzglyad na funktsii polnomochnykh predstaviteley Prezidenta Rossiyskoy Federatsii v federalnykh okrugakh v svete trebovaniy $\mathrm{k}$ strategiyam makroregionov [A New View on the Functions of Plenipotentiary Representatives of the President of the Russian Federation in the Federal Districts in the Light of Requirements to the Strategies of Macroregions]. Otechestvennaya yurisprudentsiya [Domestic Jurisprudence], no. 2, pp. 4-9.

Ukaz Prezidenta RF ot 16.01.2017 № 13 «Ob utverzhdenii Osnov gosudarstvennoy politiki regionalnogo razvitiya Rossiyskoy Federatsii na period do 2025 goda», 2017 [Decree of the President of the Russian Federation of January 16, 2017 No. 13 'On the Approval of the State Policy of Regional Development of the Russian Federation for the Period up to 2025", 2017]. Access from Reference Legal System "KonsultantPlyus".

Ukaz Prezidenta RF ot 13.05.2000 № 849 «O polnomochnom predstavitele Prezidenta Rossiyskoy Federatsii v federalnom okruge», 2010 [Decree of the President of the Russian Federation of May 16, 2000 No. 849 "On the Plenipotentiary Representative of the President of the Russian Federation in the Federal District", 2010]. Access from Reference Legal System "KonsultantPlyus". Federalnyy zakon ot 28.06.2014 № 172-FZ «O strategicheskom planirovanii $v$ Rossiyskoy Federatsii», 2014 [Federal Law of June, 282014 No. 172-FZ "On the Strategic Planning in the Russian Federation"]. Access from Information Legal Portal "GARANT". 
Federalnyy zakon ot 17.11.1999 № 211-FZ «Ob obshchikh printsipakh organizatsii $i$ deyatelnosti assotsiatsiy ekonomicheskogo vzaimodeystviya subyektov Rossiyskoy Federatsii», 1999 [Federal Law of December, 171999 No. 211-FZ “On the General Principles of the Organization and Activity of Associations of Economic Interaction of Entities of the Russian Federation"]. Access from Information Legal Portal "GARANT".

Shiryaeva A.I., 2017. Istoriya stanovleniya i razvitiya instituta polnomochnykh predstaviteley Prezidenta RF v federalnykh okrugakh [The History of Formation and Development of the Institute of the Plenipotentiary Representatives of the Russian President in Federal Districts]. Konstitutsionalizm i gosudarstvovedenie [Constitutionalism and Political Science], no. 2 (10), pp. 132-137.

Shcherbakova T.I., 2013. Sovnarkhozy: pravovoe polozhenie, ekonomicheskiy potentsial, rezultaty deyatelnosti [Economic Councils: Legal Position, Economic Potential, Results of Activities]. Ekonomicheskaya istoriya [Economic History], no. 2 (21), pp. 86-95.

\section{Information about the Authors}

Evgeniy M. Bukhvald, Doctor of Sciences (Economics), Professor, Chief Researcher, Head of the Centre of Federal Relations and Regional Development, Institute of Economics, Russian Academy of Sciences, Prosp. Nakhimovskiy, 32, 117218 Moscow, Russian Federation, buchvald@mail.ru, https:// orcid.org/0000-0001-9892-5930

Olga N. Valentik, Researcher, Centre of Federal Relations and Regional Development, Institute of Economics, Russian Academy of Sciences, Prosp. Nakhimovskiy, 32, 117218 Moscow, Russian Federation, valentik-o@ya.ru, https://orcid.org/0000-0003-0529-0855

\section{Информация об авторах}

Евгений Моисеевич Бухвальд, доктор экономических наук, профессор, главный научный сотрудник, заведующий Центром федеративных отношений и регионального развития, Институт экономики РАН, просп. Нахимовский, 32, 117218 г. Москва, Российская Федерация, buchvald@mail.ru, https://orcid.org/0000-0001-9892-5930

Ольга Николаевна Валентик, научный сотрудник Центра федеративных отношений и регионального развития, Институт экономики РАН, просп. Нахимовский, 32, 117218 г. Москва, Российская Федерация, valentik-o@ya.ru, https://orcid.org/0000-0003-0529-0855 